\title{
ANALISIS KEMAMPUAN MATEMATIKA DASAR DITINJAU DARI SELF-REGULATED LEARNING: STUDI KASUS PADA MAHASISWA SI FARMASI UNIVERSITAS MATHLA'UL ANWAR PANDEGLANG BANTEN
}

\author{
Andri Imam Subekhi' ${ }^{1)}$, Heni Pujiastuti ${ }^{2)}$ \\ ${ }^{1) 2)}$ Universitas Sultan Ageng Tirtayasa, Jl. Raya Jakarta, Kota Serang, Banten, Indonesia \\ andriimamsubekhi@gmail.com
}

\begin{abstract}
The aims of this study to analyze students basic mathematical ability in terms of students selfregulated learning (high, medium, low). This research was a descriptive qualitative research. The subjects of this study were all students of the Department of Pharmacy totaling 30 people consisting of 12 men and 18 women. To obtain data in this study used research instruments consisting of two types, namely tests and non-tests. The test instrument was a basic mathematical ability test consisting of 10 problem questions and a non-test instrument in the form of an independent learning questionnaire. Analysis of students basic mathematical ability was analyzed using a score technique and then asked for grades ranging from 0 to 100 . The scores were then classified as minimum completeness criteria (MCC). Analysis of basic mathematical ability data in terms of self-regulated learning was categorized into high, medium, and low. The results of this study indicate how to study mathematics S1 Pharmacy students at Mathla'ul Anwar Pandeglang University Banten still in the medium category with an average value of $46.67 \%$.
\end{abstract}

Keywords: Basic Mathematical Ability, Self-Regulated Learning (SRL)

\begin{abstract}
Abstrak
Penelitian ini bertujuan untuk menganalisis kemampuan matematika dasar mahasiswa ditinjau dari self-regulated learning mahasiswa (tinggi, sedang, rendah). Penelitian ini merupakan penelitian deskriptif dengan pendekatan kualitatif. Subjek penelitian ini adalah seluruh mahasiswa Jurusan Farmasi sebanyak 30 orang yang terdiri atas 12 orang laki-laki dan 18 orang perempuan. Untuk memperoleh data dalam penelitian ini digunakan instrumen penelitian yang terdiri dalam dua jenis, yaitu tes dan nontes. Instrumen tes yaitu tes kemampuan matematika dasar berupa 10 soal uraian dan instrumen non tes berupa angket self-regulated learning. Analisis kemampuan matematika dasar mahasiswa dianalisis dengan menggunakan teknik skor kemudian dikonversikan menjadi nilai dengan rentang antara 0 hingga 100. Skor tersebut selanjutnya digolongkan dalam kriteria ketuntasan minimal (KKM). Analisis data kemampuan matematika dasar ditinjau dari self regulated learning dikategorikan menjadi tinggi, sedang, dan rendah. Hasil penelitian ini menunjukkan bahwa pemahaman matematika dasar mahasiswa S1 Farmasi di Universitas Mathla'ul Anwar Pandeglang Banten mayoritas masih di kategori sedang dengan nilai rata-rata sebesar 46,67\%.
\end{abstract}

Kata kunci: Kemampuan Matematika Dasar, Self Regulated Learning (SRL)

Cara Menulis Sitasi: Subekhi, A., I., dan Pujiastuti, H. (2020). Analisis kemampuan matematika dasar ditinjau dari self-regulated learning: Studi kasus pada mahasiswa S1 farmasi Universitas Mathla'ul Anwar Pandeglang Banten. Jurnal Edukasi dan Sains Matematika (JES-MAT), 6 (1), 55 - 64. 


\section{PENDAHULUAN}

Metode pembelajaran yang digunakan pendidik sangat mempengaruhi proses dan hasil belajar pembelajar. Pembelajar akan merasa bosan dengan metode yang tidak bervariasi atau terus menerus hanya metode tertentu yang digunakan. Kondisi ini dapat menurunkan self-regulated learning belajarnya. Ketertarikan dan keinginan mahasiswa untuk terus menggali materi tertentu akan semakin menurun. Akan tetapi, faktanya banyak pendidik yang masih sering menggunakan metode ceramah dalam pembelajaran yang dilakukan di dalam kelas, sehingga perlu adanya transformasi dalam proses pengajaran yang terjadi saat ini.

Tuntutan era globalisasi adalah manusia harus memiliki kemampuan dalam memperoleh, memilih, mengelola, dan menindaklanjuti informasi-informasi yang ada untuk dimanfaatkan dalam kehidupan yang sarat tantangan, dan penuh kompetisi. Hal ini juga harus bersinergi dengan adanya kemampuan berfikir kritis, kreatif, logis, dan sistematis yang harus dimiliki oleh setiap peserta didik. Berdasarkan hasil pengamatan mengajar, selama ini proses pembelajaran pada mata kuliah matematika dasar masih menggunakan paradigma lama dimana dosen masih menjadi trade center yang memberikan pengetahuan kepada mahasiswa, sehingga mahasiswa tidak terbiasa dalam membangun pengetahuannya sendiri secara aktif. Kondisi seperti ini belum dapat meningkatkan kemampuan mahasiswa khususnya pada mata kuliah matematika dasar. Akibatnya, hasil akhir yang diperoleh mahasiswa tidak sesuai dengan yang diharapkan, bahkan nilai rata-ratanya berada dibawah KKM yang sudah ditetapkan.

Dengan adanya motivasi belajar diharapkan mahasiswa menjadi lebih aktif, bersemangat dan terlibat total dalam proses pembelajaran sehingga setiap kegiatan dilakukan dengan keinginan untuk berkembang. Cara yang harus dilakukan adalah dengan mengembangkan kemampuan mahasiswa itu sendiri. Mahasiswa agar dapat belajar sendiri dan tidak terlalu bergantung dengan sumber atau bantuan lainnya. Kemandirian sangat diperlukan dalam memperbaharui keaktifan mahasiswa. Kemandirian dapat merangsang mahasiswa untuk lebih bersemangat dan aktif dalam belajar. Hal ini disebabkan karena kemandirian muncul dari diri sendiri, keinginan dan motivasi mahasiswa sendiri. Dengan semangat kemandirian yang tumbuh dari dalam diri mahasiswa, tidak menutup kemungkinan akan munculnya kemampuan berfikir tingkat tinggi dan hasil belajar yang lebih baik. Apabila mahasiswa sudah merasa nyaman dan menyenangkan secara pribadi, mahasiswa akan terdorong untuk memperbaharui hasil belajarnya, dari perubahan pola kemandirian belajar tersebut.

Dalam pengajaran matematika dasar, mahasiswa diharapkan mampu belajar mandiri dan terdapat peningkatan cara berfikir, karena matematika adalah ilmu hitung yang harus dikaji secara lebih dalam agar mendapatkan hasil belajar yang memuaskan. Namun demikian kemampuan belajar mandiri, berfikir tingkat tinggi dan hasil belajar adalah satu keterkaitan yang harus ada. Kemandirian dan berfikir tingkat tinggi akan mendidik dan menuntun mahasiswa dalam belajar 
sehingga tidak sekedar menanti hasil belajar yang baik.

Penyebab-penyebab tersebut dapat muncul dari dosen, mahasiswa, lingkungan ataupun sarana prasarana. Suasana pembelajaran dosen kadang menciptakan proses pembelajaran yang menjenuhkan dan kurang membangun mahasiswa untuk tertantang. Oleh karena itu, mahasiswa menjadi jenuh dalam suasana kelas. Selain itu, mahasiswa juga tidak mampu belajar aktif, sementara seharusnya mahasiswa mampu belajar mandiri sehingga dapat berimplikasi pada pemikiran tingkat tinggi.

Hasil survei yang dilakukan pada mahasiswa S1 Farmasi Universitas Mathla'ul Anwar Pandeglang Banten, mahasiswa pada umumnya banyak mengalami kesulitan pada pokok bahasan Matematika Dasar seperti himpunan, deret, barisan geometri, sistem persamaan linier, sitem persamaan linier satu variabel, sistem persamaan linier dua variabel, program linier, aljabar dan statistika. Padahal, pokok bahasan tersebut merupakan pokok bahasan yang harus dikuasai sebagai syarat mengambil mata kuliah Matematika Dasar di Jurusan Farmasi, dimana penyelesaian permasalahannya membutuhkan tingkat kemampuan berfikir yang tinggi.

Menurut Lestari dan Widada (2017), dalam proses pembelajaran matematika terdapat metode self-regulated learning (kemandirian belajar). Menurut Istiningrum (2017), self-regulated learning merupakan karakter seseorang yang mempunyai inisiatif belajar, menganalisis kebutuhan belajar, menetapkan tujuan belajar, mengontrol pembelajaran, memiliki pandangan bahwa tantangan dalam belajar pasti ada kesulitan, tetapi dapat memiliki kemampuan untuk mencari solusi dengan mencari sumber belajar yang mudah dipelajari, kemudian menerapkannya dan digunakan untuk mengevaluasi sendiri hasil belajarnya. Adanya kemampuan self-regulated learning dapat menghasilkan dampak yang positif bagi siswa agar terus mendapatkan kepercayaan diri terhadap kemampuan pribadi dan mengantisipasi adanya dampak yang kurang baik pada saat proses pembelajaran, maupun hasil yang akan didapatkan.

Konsep merupakan suatu objek penting dalam matematika. Matematika itu sendiri dibangun dari sejumlah konsep. Konsep-konsep tersebut saling berhubungan karena konsep sebelumnya akan menjadi dasar bagi konsep selanjutnya. O'Connell (2007) menyatakan bahwa peserta didik akan lebih mudah dalam memecahkan permasalahan apabila peserta didik akan mampu mengaitkan hubungan antar konsep dengan dasar konsep yang telah dipahami. Transfer ilmu akan lebih mudah apabila peserta didik sudah mempunyai pemahaman konsep. Apabila belum memahami konsep, peserta didik akan mengalami kesulitan belajar dalam memahami materi selanjutnya, hal inilah yang menyebabkan peserta didik menganggap matematika merupakan pelajaran yang sulit.

Pemahaman konsep ini merupakan salah satu aspek yang harus dikembangkan dalam pembelajaran matematika. Pembelajaran matematika diperlukan konsep pemahaman. Pembelajaran matematika sebaiknya dirancang dengan menggunakan pendekatan atau model yang efektif sehingga dapat memberikan respon positif berupa pemahaman konsep pada peserta didik (Narendrati, 2017). Pemahaman konsep matematis dapat 
dipandang sebagai proses dan tujuan dari suatu pembelajaran matematika. Pemahaman konsep itu sendiri adalah kemampuan peserta didik dalam domain kognitif yang terutama berkenaan dengan pengetahuan, pengertian, dan penerapan seperti dalam Taxonomy Bloom. Pemahaman konsep peserta didik dalam matematika sangat penting karena akan memudahkan peserta didik dalam mempelajari matematika. Pemahaman konsep tidak hanya sekedar mengerti dan mengingat materi yang diajarkannya saja tetapi juga harus mampu menjelaskan kembali dan mengaplikasikannya dalam bentuk lain yang masih berkaitan baik dengan matematika dalam bentuk lisan maupun tulisan.

Konsep pembelajaran yang tepat untuk siswa adalah harup memahami materi yang diberikan oleh dosen. Kemampuan pemahaman matematika merupakan pemahaman yang mampu mengubah (translation) soal kata-kata ke dalam simbol dan sebaliknya, mampu mengartikan (interpretation) suatu kesamaan, mampu memperkirakan (extrapolation) suatu kecenderungan dari gambar (Ruseffendi, 1998). Pemahaman adalah suatu keadaan yang menunjukan sejauh mana mahasiswa dapat menyelesaikan masalah dengan benar dengan caranya sendiri berdasarkan pengetahuan yang sudah didapatnya. Oleh karena itu dalam proses pembelajaran tentang konsep harus disertai oleh contoh dan juga memperlihatkan yang bukan contoh dari konsep itu. Proses pembelajaran tidak boleh hanya mengenalkan sesuatu yang baru. Namun diharapkan adanya peningkatan pengetahuan yang sudah dimiliki.
Self-regulated learning merupakan sikap siswa atau peserta didik yang lebih aktif dalam mengembangkan ilmu pengetahuan yang telah diperoleh dengan menggunakan metode yang relevan terlepas dari materi yang diperoleh siswa di dalam kelas formal (Hui, 2011). Fitria (2009) menyatakan bahwa, konsep ini didasari oleh sifat konstruktivisme (perancangan dan pengelolaan sistem pembelajaran yang mampu memotivasi peserta didik dalam mengeksplorasi pengalaman pribadi menjadi pengetahuan yang dapat diterapkan di dalam kelas..

Metode perkuliahan pada Jurusan Farmasi Universitas Mathla'ul Anwar Pandeglang Banten adalah dalam bentuk perkuliahan secara umum, dimana terdapat moodle, pekerjaan rumah dan demonstrasi yang diaplikasikan dalam rangka peningkatan minat belajar aktif untuk mahasiswa sendiri. Dalam kondisi tersebut, mahasiswa diharuskan dapat mempelajari konsep yang lebih tinggi kualitasnya agar dapat berpikir lebih jauh dalam menerima konsep dasar di kelas. Pengalaman mengajar penulis menunjukkan bahwa mata kuliah matematika dasar merupakan mata kuliah dasar dengan materi yang membutuhkan tingkat berpikir lebih tinggi dibandingkan mata kuliah lain. Grove (Flynn, 2014) menyebutkan bahwa tingkat kegagalan memahami materi pada mata kuliah ini juga cukup tinggi karena mahasiswa mengalami kesalahan konseptual.

Berdasarkan latar belakang tersebut, penelitian ini dilakukan dengan tujuan untuk menganalisis kemampuan matematika dasar khususnya pada mahasiswa Jurusan S1 Farmasi Universitas Mathla'ul Anwar Pandeglang Banten ditinjau dari self regulated 
learning mahasiswa (tinggi, sedang, rendah).

\section{LANDASAN/KAJIAN TEORI}

Kemampuan Matematika Dasar

Matakuliah matematika dasar mahasiswa memahami dan dapat mengerjakan soal himpunan, deret, barisan geometri, sistem persamaan linier, sitem persamaan linier satu variabel, sistem persamaan linier dua variabel, program linier, aljabar dan statistika. Adapun indikator kemampuan matematika dasar adalah mengklasifikasikan objek, mengidentifikasi objek, menyajikan objek, mengaplikasikan objek dan mengembangkan objek yang dituangkan dalam bentuk tes uraian sebanyak sepuluh soal.

\section{Self Regulated Learning}

Self-regulated learning merupakan sikap siswa atau peserta didik yang lebih aktif dalam mengembangkan ilmu pengetahuan yang telah diperoleh dengan menggunakan metode yang relevan terlepas dari materi yang diperoleh siswa di dalam kelas formal (Hui, 2011). Menurut pendapat Elyaniar (2012) bahwa terdapat 4 prinsip dasar dari self-regulated learning yaitu persiapan lingkungan belajar, pengorganisasian materi pembelajaran, pemantauan kemajuan pribadi, dan pelaksanaan evaluasi diri.

\section{METODE PENELITIAN}

\section{Jenis Penelitian}

Metode yang digunakan pada penelitian ini adalah analisis deskriptif kualitatif.

\section{Waktu dan Tempat Penelitian}

Penelitian ini dilaksanakan pada semester gasal tahun akademik 2019/2020, di Universitas Mathla'ul Anwar Pandeglang Banten.

\section{Subjek Penelitian}

Subjek penelitian ini adalah 30 orang mahasiswa yang terdiri dari 18 mahasiswa laki-laki dan 12 mahasiswa perempuan pada Program Studi S1 Farmasi di Universitas Mathla'ul Anwar Pandeglang Banten. Mahasiswa yang menjadi subjek dalam penelitian ini adalah mahasiswa yang memprogram mata kuliah matematika dasar pada semester gasal tahun akademik 2019/2020

\section{Data, Intrumen, dan Teknik Pengumpulan Data}

Instrumen yang digunakan untuk penelitian ini berupa angket. Angket disusun secara terstruktur dengan meyediakan pilihan jawaban, sehingga responden hanya tinggal memberi tanda pada jawaban yang dipilih. Bentuk jawaban angket berupa tertutup, artinya pada setiap butir sudah tersedia berbagai alternatif jawaban yang dipilih. Angket bersifat inventori tes, yaitu tidak ada jawaban benar atau salah dengan lima kategori respon. Skala disusun dengan model skala Likert yang memiliki bobot skor 1-5 kepada mahasiswa. Butir tes diadaptasi dari penelitian Anwar (2019). Penelitian juga menggunakan angket essay yang berisi 10 soal essay yang diberikan kepada mahasiswa dan soal essay dengan materi yang merupakan syarat mengambil matakuliah matematika dasar mahasiswa memahami dan dapat mengerjakan soal himpunan, deret, barisan geometri, sistem persamaan linier, sitem persamaan linier satu variabel, sistem persamaan linier dua 
variabel, program linier, aljabar dan statistika.

\section{Teknik Analisis Data}

Hasil yang diperoleh dikonversi sehingga menjadi nilai dengan rentang antara 0 sampai dengan 100. Skor tersebut kemudian digolongkan dalam Kriteria Ketuntasan Minimal (KKM) dengan skor 60. Adapun indikator kemampuan matematika dasar adalah mengklasifikasikan objek, mengidentifikasi objek, menyajikan objek, mengaplikasikan objek dan mengembangkan objek yang dituangkan dalam bentuk tes uraian sebanyak sepuluh soal. Untuk mengkategorisasikan SRL tersebut digunakan rata-rata dan simpangan baku dari keseluruhan data peserta mahasiswa seperti yang disajikan pada Tabel 1. Hasil penelitian berupa analisis kemampuan matematika dasar ditinjau dari self regulated learning mahasiswa menggunakan kategori tinggi, sedang, dan rendah.

Tabel 1. Kategorisasi SRL

\begin{tabular}{cc}
\hline Taraf & $\begin{array}{c}\text { Skor SRL } \\
\text { Kelas Eksperimen }\end{array}$ \\
\hline Tinggi & Skor 99 \\
Sedang & $60<$ Skor $<98$ \\
Rendah & Skor 59 \\
\hline
\end{tabular}

Sumber: Lestari \& Yudhanegara (2017)

\section{HASIL PENELITIAN DAN PEMBAHASAN}

\section{Hasil Penelitian}

Data kemampuan matematika dasar diukur berdasarkan faktor SRL (tinggi, sedang, rendah) yang diperlakukan baik pada kelas eksperimen. Self regulated learning ini terkait dengan materi atau pengalaman selama proses pembelajaran yang pernah diperoleh mahasiswa selama Sekolah Menengah Atas atau Sekolah Menengah Kejuruan (SMA/SMK). Diukur dengan kategori soal pernyataan berupa pilihan yaitu: 1) sangat setuju (SS), 2) setuju (S), 3) Netral (N), 4) sangat tidak setuju (STS) dan 5) tidak setuju (TS) yang diberikan ke pada mahasiswa dengan disediakan tanda ceklist yang tersedia di form pernyataan. setelah jawaban mahasiswa terkumpul kemudian direkap, dan diolah berdasarkan penggolongan kategori SRL tinggi (T), sedang (S), dan rendah (R) berdasarkan skor yang diperoleh masing-masing mahasiswa.

Untuk mengkategorisasikan SRL tersebut digunakan rata-rata dan simpangan baku dari keseluruhan data peserta mahasiswa. SRL keseluruhan kelas eksperimen rata-rata adalah 68,66. Sedangkan untuk simpangan baku kelas eksperimen adalah 7,64. Kemudian dilakukan batas-batas kategori SRL (tinggi, sedang, rendah) yang diperoleh berdarkan rata-rata dan simpangan baku seperti pada Tabel 1.

Kategorisasi sebagaimana pada Tabel 1 di atas digunakan untuk mengkategorisasi SRL pada satu kelompok mahasiswa yaitu kelompok 
pembelajaran dengan kemampuan matematika dasar. Berikut adalah sebaran data jumlah sampel pada kategori self- regulated learning (SRL) untuk kelompok pembelajaran eksperimen kemampuan matematika dasar.

Tabel 2. Jumlah Sampel Berdasarkan SRL

\begin{tabular}{cc}
\hline Kategori SRL & $\begin{array}{c}\text { Eksperimen analisis } \\
\text { kemampuan matematika } \\
\text { dasar }\end{array}$ \\
\hline Tinggi & 0 \\
Sedang & 27 \\
Rendah & 3 \\
Total Mahasiswa & 30 \\
\hline
\end{tabular}

Jumlah mahasiswa dalam sampel berdasarkan kategori SRL pada kelompok pembelajaran kemampuan matematika dasar sama-sama cenderung normal. Jumlah mahasiswa pada kelompok kategori Rendah lebih sedikit dan jumlah mahasiswa pada kategori sedang lebih banyak. Hasil data tes mahasiswa sesudah dilaksanakannya pembelajaran kemampuan matematika dasar ditinjau dari self-regulated learning (tinggi, sedang, rendah) di kelas Farmasi B Universitas Mathla'ul Anwar Pandeglang Banten .

Tabel 3. Tabel Distribusi Frekuensi Kemampuan matematika dasar mahasiswa

\begin{tabular}{cccc}
\hline No & Kelas Interval & Frekuensi & $\begin{array}{c}\text { Frekuensi } \\
(\mathbf{1 0 0 \%})\end{array}$ \\
\hline 1 & $20-30$ & 0 & 0 \\
2 & $31-41$ & 0 & 0 \\
3 & $42-52$ & 0 & 0 \\
4 & $53-63$ & 5 & 16,67 \\
5 & $64-74$ & 14 & 46,67 \\
6 & $75-85$ & 11 & 36,66 \\
& Jumlah & 30 & 100 \\
\hline
\end{tabular}

Dari tabel 3 tersebut dapat dibuat menjadi diagram batang seperti pada gambar berikut ini : 


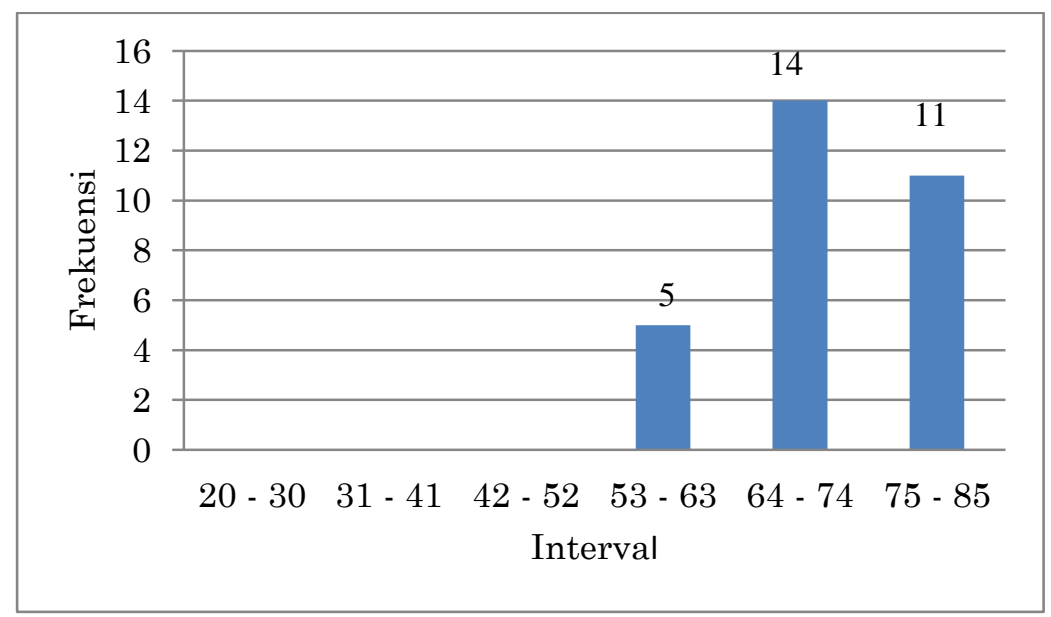

Gambar 1. Diagram Distribusi Frekuensi Kemampuan Matematika Dasar Mahasiswa

Dari gambar 1 menunjukan bahwa diagram distribusi frekuensi penilaian kemampuan matematika dasar menyatakan bahwa kelas interval dan frekuensi sebagai berikut (20 - 30) sebanyak 0 mahasiswa, (31 - 41) sebanyak 0 mahasiswa, (42 - 52) sebanyak 0 mahasiswa, (53 - 63) sebanyak 5 mahasiswa, (64 - 74) sebanyak 14 mahasiswa, dan (75 - 85) sebanyak 11 mahasiswa. Kemampuan pemahaman matematika dasar mahasiswa didominasi pada kelas interval pertama, 64 - 74 yaitu sebanyak 14 mahasiswa atau 46,67\% dari 30 mahasiswa sedangkan frekuensi skor kemampuan pemahaman matematika dasar mahasiswa paling sedikit berada pada kelas interval keempat dengan skor 53 63 yaitu sebanyak 5 mahasiswa atau pada persentase $16,67 \%$.

Kemampuan

pemahaman

matematika dasar mahasiswa secara keseluruhan pada materi matematika dasar tergolong sedang. Hal ini dapat dilihat dari nilai rata-rata mahasiswa dalam menyelesaikan tes kemampuan pemahaman matematika dasar mahasiswa yaitu 68. Pada diagram 1 nampak mayoritas mahasiswa kemampuan pemahaman matematika dasar mahasiswa berada pada kelas interval $64-74$ sebanyak 14 mahasiswa atau 46,67\% dari banyaknya mahasiswa. mahasiswa yang memiliki kemampuan pemahaman matematika dasar mahasiswa pada materi himpunan, deret, barisan geometri, sistem persamaan linier, sitem persamaan linier satu variabel, sistem persamaan linier dua variabel, program linier, aljabar dan statistika yang melampaui kriteria ketuntasan minimal (KKM) yaitu siswa yang memperoleh nilai antara $75-85$ sebanyak 11 mahasiswa atau 36,66\% dari banyaknya mahasiswa.

\section{Pembahasan}

Dalam proses pembelajaran matematika, pemahaman konsep matematika dasar merupakan bagian yang sangat penting. Pemahaman konsep matematika dasar merupakan landasan penting untuk berpikir dalam menyelesaikan permasalahan matematika maupun permasalahan sehari-hari.

Pada penelitian ini menempati frekuensi skor minat belajar peserta didik paling banyak dengan interval skor 64 hingga 74 pada persentase $46,67 \%$ yakni 
14 dari 30 peserta didik sedangkan frekuensi skor minat belajar peserta didik paling sedikit berada pada interval 53 hingga 63 dengan persentasi $16,67 \%$ yakni 5 dari 30 peserta didik. Lebih dari setengah mahasiswa di kelas tersebut memiliki minat belajar dalam kategori sedang dan masih di bawah rata-rata KKM, dengan persentase sebesar $46,67 \%$ dalam kemampuan matematika dasar. Hal ini berbeda dengan hasil penelitian Trisnawati (2018) yang meneliti tentang selfregulated learning pada mahasiswa Kimia di Universitas Negeri Malang menunjukkan bahwa mahasiswa yang memiliki self-regulated learning tinggi lebih banyak $(52,94 \%)$ daripada mahasiswa yang memiliki self-regulated learning rendah (47,06 \%). Anwar et al. (2019) menyebutkan bahwa self-regulated learning berpengaruh terhadap kemampuan koneksi matematis peserta didik. Lestari et al. (2017) menjelaskan bahwa besar pengaruh strategi pembelajaran self-regulated learning pada pembelajaran matematika berbasis pemecahan masalah terhadap kemampuan metakognitif peserta didik sebesar 31,8\%.

Berdasarkan penelitian Edistria et al. (2019), dalam meningkatkan kemampuan self-regulated learning mahasiswa yang lebih baik dapat menggunakan penerapan hypnoteaching yang dilakukan pada mahasiswa Papua. Hal ini dapat dilihat dari persentase skor sikap terkait kemampuan self-regulated learning yang mengalami peningkatan dari awalnya sebesar $61 \%$ pada pra siklus, meningkat menjadi $72 \%$ pada siklus I dan $74 \%$ pada siklus II. Terkait respon mahasiswa diperoleh kesimpulan bahwa mahasiswa memberikan respon positif terhadap penerapan hypnoteaching yang dilakukan.

\section{SIMPULAN DAN SARAN \\ Simpulan}

Dalam penelitian ini dapat disimpulkan bahwa kemampuan pemahaman matematika dasar S1 mahasiswa kelas Farmasi B Universitas Mathla'ul Anwar Pandeglang, Banten masih sedang. Hal ini ditandai dengan banyaknya siswa yang memiliki nilai di bawah kriteria ketuntasan minimal (KKM). Kondisi minat belajar yang dialami mahasiswa termasuk pada tingkat kategori sedang sehingga mengakibatkan mahasiswa kurang memahami dan memotivasi diri terhadap kemampuan matematika dasar sebagai syarat memahami materi perkuliahan di semester 1 pada matakuliah matematika dasar 1 di Jurusan Farmasi Fakultas Sains Farmasi dan Kesehatan Universias Mathla'ul Anwar Pandeglang, Banten.

\section{Saran}

$\begin{array}{llr}\text { hendaknya } & \text { seorang } & \text { pendidik }\end{array}$ memperhatikan self-regulated learning mahasiswa. hal tersebut dikarenakan selfregulated learning berpengaruh terhadap hasil belajar mahasiswa. perlu dilakukan penelitian yang mengupayakan untuk memfasilitasi peningkatan kemampuan mahasiswa pada mata kuliah matematika dasar.

\section{DAFTAR PUSTAKA}

Anwar, S., Pujiastuti, H., \& Mutaqin, A. (2019). Pengaruh Contextual Teaching and Learning dan Self 
Regulated Learning Terhadap Kemampuan Koneksi Matematis, 3(2), 116-133.

Edistria, E., B. Rahman, A. A. Abdillah. (2019). Penerapan Hypnoteaching Untuk Meningkatkan Kemampuan Self-Regulated Learning Mahasiswa Papua Dalam Mata Kuliah Desain Pembelajaran. Epigram, 16 (10) : 73-90.

Flynn, A.B. (2014). Structure and evaluation of flipped chemistry course: organic dan spectroscopy, large and small, first to third year, English and French, Journal of Chemistry Education Research and Practice.

Hui, T. H. (2011). Does a combination of metaphor and pairing activity help programming performance of students with different selfregulated learning level?, TOJET: The Turkish Online Journal of Educational Technology, 10 (4) : 121-129.

Istiningrum, A. A. (2017). Peningkatan selfregulated learning skills mahasiswa pada mata kuliah akuntansi pengantar melalui problem-based learning, Cakrawala Pendidikan, 36 (1) : 81-90.

Lestari, K. E, dan Yudhanegara, M.R. (2017). Penelitian Pendidikan Matematika. Bandung: Refika Aditama.

Lestari, N. A., \& Widada, W. (2017). Pengaruh Strategi Pembelajaran Self Regulated Learning In Mathematics Berbasis Pemecahan Masalah Terhadap Kemampuan Metakognitif Siswa Di Sma Negeri 2 Bengkulu,
Jurnal Pendidikan Matematika

Raflesia, 2 (2): 151-60

Narendrati, N. (2017). Komparasi Pembelajaran Statistika Melalui Pendekatan CTL dan ProblemPosing Ditinjau dari Prestasi Belajar dan Minat Belajar Matematika $A$ Comparison of Statistics Learning Through CTL and Problem-Posing Approach in Terms of Learning Achievement and Intere, 4(1), 67-77.

Ruseffendi, E. (1998). Pengantar Kepada Membantu Guru Mengembangkan Kompetensinya dalam Pengaaran Matematika Untuk Meningkatkan CBSA. Bandung: Tarsito.

Trisnawati, A. (2018). Self-Regulated Learning Mahasiswa Pada Pembelajaran Kooperatif STAD dipadu dengan Blended Learning Dalam Mata Kuliah Kimia Analisis Instrumentasi. J. Pijar MIPA. 8(1) : 6-12. 